The Paradox of Urban Revitalization 


\title{
THE CITY IN THE TWENTY-FIRST CENTURY
}

\author{
Series Editors
}

Eugenie L. Birch and Susan M. Wachter,

A complete list of books in the series is available from the publisher. 


\title{
THE PARADOX OF \\ URBAN REVITALIZATION
}

\author{
Progress and Poverty in America's \\ Postindustrial Era
}

\section{Howard Gillette, Jr.}

\author{
$\overline{\text { PENN }}$ \\ UNIVERSITY OF PENNSYLVANIA PRESS \\ PHILA DELPHIA
}


Copyright @ 2022 University of Pennsylvania Press

All rights reserved. Except for brief quotations used for purposes of review or scholarly citation, none of this book may be reproduced in any form by any means without written permission from the publisher.

$$
\begin{gathered}
\text { Published by } \\
\text { University of Pennsylvania Press } \\
\text { Philadelphia, Pennsylvania 19104-4112 } \\
\text { www.upenn.edu/pennpress }
\end{gathered}
$$

Printed in the United States of America on acid-free paper 109877654321

Library of Congress Cataloging-in-Publication Data

Names: Gillette, Howard, Jr., 1942- author.

Title: The paradox of urban revitalization : progress and poverty in America’s postindustrial era / Howard Gillette, Jr.

Other titles: City in the twenty-first century book series.

Description: 1st edition. | Philadelphia : University of

Pennsylvania Press, [2022] | Series: The city in the twenty-first century | Includes bibliographical references and index.

Identifiers: LCCN 2021039346 | ISBN 9780812253719

(hardcover), ISBN 9780812298338 (eBook)

Subjects: LCSH: Urban renewal-United States-Case studies. | Urban policy_-United States-Case studies. | Sociology, Urban-United States. | Equality-United States.

Classification: LCC HT175 .G55 2022 |

DDC 307.3/4160973-dc23

LC record available at https://lccn.loc.gov/2021039346 
For Margaret 
